\title{
OPTIMASI PEMBUATAN SOHUN UBI JALAR MENGGUNAKAN EKSTRUDER PEMASAK-PENCETAK
}

\author{
[Optimization of Sweet Potato Vermicelli Production Using Cooking-Forming Extruder]
}

\author{
Tjahja Muhandri ${ }^{1,2) \star}$, Subarna ${ }^{1,2)}$, Sutrisno Koswara ${ }^{1,2)}$, Budi Nurtama ${ }^{1)}$, \\ Dimas Imam Ariefianto ${ }^{3)}$, dan Dewi Fatmala ${ }^{3)}$ \\ 1) Departemen Ilmu dan Teknologi Pangan, Fakultas Teknologi Pertanian, Institut Pertanian Bogor, Bogor \\ 2) Southeast Asian Food and Agricultural Science and Tecnology Center, Institut Pertanian Bogor, Bogor \\ 3) Program Sarjana, Fakultas Teknologi Pertanian, Institut Pertanian Bogor, Bogor
}

Diterima 05 Januari 2017 / Disetujui 12 Juni 2017

\begin{abstract}
Sweet potatoes have a fairly diverse varieties and the difference in varieties is assumed to influence the starch physicochemical properties. The objective of this research was to optimize the sweet potato vermicelli production using a cooking-forming extruder. The starch characterization included proximate analysis, starch content, amylose content and gelatinization profile. Sweet potato vermicelli was made with the starch of sweet potaoto Ace variety. Meanwhile, process and formula optimization was carried out using Response Surface Methodology (RSM). The amount of starch used was in the range of 62.5-69.0 g, the amount of water was 31.0-37.5 g, extruder temperature of $80-90^{\circ} \mathrm{C}$ and screw rotation of $90-120 \mathrm{rpm}$. The starch of sweet potato Ace variety had the highest level of carbohydrate, total starch and amylose $(99.16,86.91$, and $8.77 \% \mathrm{db}$, respectively). It also had the mostexcellentcooking endurance as shown by the lowest breakdown viscosity $(5183.33 \mathrm{cP})$, and the best tendency of retrogradation as shown by the highest setb ack viscosity $(1328.00 \mathrm{cP})$. The optimum combination for the vermicelli making was $65.2 \mathrm{~g}$ of starch, $34.8 \mathrm{~g}$ of water, extruder temperature of $85^{\circ} \mathrm{C}$ and screw rotation of $115 \mathrm{rpm}$. The sweet potato vermicelli from the optimum condition resulted in $20.85 \%$ actual cooking loss and $164.98 \%$ elongation. Process improvement with freezing and fan drying of the vermicelli produced a better quality of vermicelli with $12.90 \%$ cooking loss and $196.42 \%$ elongation.
\end{abstract}

Keywords: optimization, RSM, sweet potato starch, vermicelli

\begin{abstract}
ABSTRAK
Ubi jalar memiliki varietas yang cukup beragam, dan perbedaan varietas diduga memberikan pengaruh kepada sifat fisikokimia pati yang dihasilkan. Tujuan penelitian ini adalah optimasi pembuatan sohun dari pati ubi jalar menggunakan ekstruder pemasak-pencetak. Karakterisasi pati ubi jalar meliputi analis is proks imat, kadar pati, kadar amilosa serta profil gelatinisasi. Optimasi proses dan formula sohun ubi jalar pati varietas Ace menggunakan alat bantu Response Surface Methodology (RSM). Kisaran jumlah pati yang digunakan yaitu $62,5-69,0 \mathrm{~g}$, jumlah air $31,0-37,5 \mathrm{~g}$, suhu ekstruder $80-90^{\circ} \mathrm{C}$, dan kecepatan ulir ekstruder 90-120 rpm. Pati ubi jalar varietas Ace memiliki kadar karbohidrat, total pati dan amilosa paling tinggi $(99,16 ; 86,91$; dan $8,77 \%$ bk), dan memiliki ketahanan dalam pemasakan paling baik, yang ditunjukkan oleh breakdown viscosity yang paling rendah $(5183,33 \mathrm{cP})$ dan memiliki kecenderungan retrogradasi paling tinggi, yang ditunjukkan oleh setback viscosity yang paling tinggi $(1328,00 \mathrm{cP})$. Kombinasi optimum untuk sohun ubi jalar yaitu jum lah pati $65,2 \mathrm{~g}$, jumlah air $34,8 \mathrm{~g}$, suhu eks truder $85^{\circ} \mathrm{C}$, dan kecepatan ulir ekstruder $115 \mathrm{rpm}$. Sohun ubi jalar yang dihasilkan dari kombin asi optimum memiliki nilai aktual kehilangan padatan akibat pemasakan (KPAP) 20,85\% dan elongasi 164,98\%. Perbaikan proses dengan pembekuan sohun dan pengeringan menggunakan kipas angin menghasilkan sohun dengan mutu yang lebih baik yaitu KPAP 12,90\% dan elongasi 196,42\%.
\end{abstract}

Kata kunci: optimasi, pati ubi jalar, RSM, sohun

\section{PENDAHULUAN}

Sohun merupakan salah satu jenis mi nonterigu berbahan dasar pati yang berasal dari be-

*Penulis Korespondensi:

E-mail: cahyomuhandri@yahoo.com berapa jenis tumbuhan (Fu, 2007). Sohun dapat dan aman dikonsumsi untuk semua golongan, termasuk penderita autis karena merupakan produk bebas gluten (Widowati et al., 2014). Pati ubi jalar merupakan bahan baku yang potensial untuk membuat sohun karena harganya yang murah, tersedia cukup melimpah di Bogor dan memiliki indeks glikemik 
yang rendah (Astawan dan Widowati, 2011). Berdasarkan diskusi dengan petani di Cikarawang dan Ciampea, Kabupaten Bogor, varietas ubi jalar yang banyak ditanam di daerah Bogor adalah Sukuh, Ace, Cangkuang, dan Sawentar. Kriteria kualitas utama produk sohun adalah cooking weight, cooking loss, dan tekstur (Tan et al., 2009). Menurut Chen et al. (2002), sohun dari pati ubi jalar varietas tertentu memiliki kualitas yang mendekati kualitas sohun dari pati kacang hijau. Thao dan Noomhorm (2011) menyatakan bahwa penambahan $20 \%$ pati ubi jalar tidak berbeda secara signifikan dengan kualitas sohun dari pati kacang hijau 100\%.

Chen et al. (2002) melakukan penelitian pembuatan sohun dari pati beberapa varietas ubi jalar. Pati ubi jalar sebanyak $5 \%$ digelatinisasi dengan air (1:9 b/v), lalu dicampur dengan $95 \%$ pati kering. Pencampuran dilakukan pada suhu $40^{\circ} \mathrm{C}$ dengan kadar air 55\% lalu dimasukkan ke dalam ekstruder untuk membentuk untaian sohun berdiameter 1.5 $\mathrm{mm}$. Sohun ditampung dalam air panas $\left(95-98^{\circ} \mathrm{C}\right)$ selama 50-70 detik kemudian dipindahkan ke dalam air dingin bersuhu $4^{\circ} \mathrm{C}$ selama 6 jam, lalu dibekukan pada suhu $-5^{\circ} \mathrm{C}$ selama 8 jam, setelah itu dikeringanginkan. Proses pendinginan dan pembekuan dapat mempercepat proses retrogradasi sehingga dapat memperbaiki struktur sohun (Tan et al., 2009). Pembuatan mi pati (sohun) telah dilakukan masyarakat, namun prosesnya memakan waktu lama, menghasilkan limbah cair, dan tidak efisien (Charutigon et al., 2008). Teknologi ekstrusi pemasak-pencetak telah mampu menghasilkan produk sohun yang lebih baik jika dibandingkan dengan metode pengolahan tradisional Ekstrusi pemasak-pencetak menggabungkan unit operasi transportasi, pencampuran, pengolahan termal, dan pencetakan dalam satu alat (Noda et al., 2006). Penelitian pembuatan sohun ubi jalar menggunakan ekstruder pemasak-pencetak belum banyak dilakukan. Penelitian ini ini bertujuan untuk optimasi pembuatan sohun dengan bahan baku pati ubi jalar. Proses pembuatan sohun ubi jalar menggunakan ekstruder pemasak-pencetak. Mutu sohun ubi jalar yang dihasilkan dibandingkan dengan sohun komersial.

\section{BAHAN DAN METODE}

\section{Bahan}

Bahan baku utama yang digunakan dalam penelitian ini adalah ubi jalar varietas Sukuh, Ace, Cangkuang, dan Sawentar (Kelompok Tani di Desa Cikarawang, Bogor).

\section{Pembuatan pati ubi jalar (Adedotun et al., 2015 dengan modifikasi)}

Ubi jalar dicuci menggunakan air bersih kemudian dikupas menggunakan pisau. Ubi diparut lalu direndam dengan larutan Natrium Metabisulfit (Sigma, USA) dengan konsentrasi $0,1 \%$ selama 15 menit. Perbandingan antara larutan sulfit yang digunakan dengan hasil parutan ubi adalah 4:1 (v/b). Parutan ubi diperas dan disaring. Suspensi pati diendapkan selama 2 jam, filtratnya dibuang. Endapan pati dicuci menggunakan air dan diendapkan kembali. Proses ini diulang selama tiga kali hingga filtrat yang dihasilkan jernih. Pati dikeringkan dalam oven pengering (Cascade Tek, Indonesia) bersuhu $50^{\circ} \mathrm{C}$ selama 4 jam. Pati kering digiling dengan blender (Philips, Indonesia) lalu dilakukan pengayakan 100 mesh.

\section{Karakterisasi pati ubi jalar}

Karakterisasi dilakukan dengan analisis proksimat (AOAC, 2005) yang meliputi kadar air metode oven, kadar abu, kadar protein metode kjeldahl, kadar lemak metode soxhlet, dan kadar karbohidrat by difference. Selain itu dilakukan analisis kadar pati total, kadar amilosa (Juliano, 1971) dan analisis profil gelatinisasi pati (Noda et al., 2015). Ubi jalar yang digunakan dalam optimasi pembuatan sohun adalah varietas yang memiliki kandungan pati paling tinggi dan memiliki sifat pasting properties yang lebih baik (swelling power dan gel strength lebih rendah serta Setback Viscosity yang lebih tinggi).

\section{Penentuan faktor dalam optimasi sohun ubi jalar}

Tahapan ini dilakukan untuk menetapkan kisaran faktor dengan metode trial and error untuk menetapkan batas bawah dan batas atas yang dimasukkan ke dalam program RSM adalah Design Expert 7 (DX7). Pada penelitian ini faktor yang dipelajari adalah jumlah air, jumlah pati ubi jalar, suhu ekstruder, dan kecepatan ulir ekstruder. Kondisi minimum dan maksimum dari keempat faktor yang diperoleh dari tahap penelitian ini disajikan pada Tabel 1.

Tabel 1. Kisaran variabel bahan dan proses yang digunakan dalam penelitian

\begin{tabular}{lcc}
\hline \multirow{2}{*}{ Faktor } & \multicolumn{2}{c}{ Percobaan } \\
\cline { 2 - 3 } & Minimum & Maksimum \\
\hline Air (gr) & 31,0 & 37,5 \\
Pati (gr) & 62,5 & 69,0 \\
Suhu ekstruder $\left({ }^{\circ} \mathrm{C}\right)$ & 80 & 90 \\
Kecepatan ulir & 80 & 120 \\
ekstruder (rpm) & \multicolumn{2}{|}{} \\
\hline
\end{tabular}

\section{Rancangan formulasi, proses, dan respon meng- gunakan RSM}

Software yang digunakan pada penelitian ini adalah DX7 (Combined Design). Variabel tetap pada penelitian ini adalah jumlah penggunaan garam $(2 \%$ dari jumlah pati). Variabel bebasnya adalah jumlah air, jumlah pati ubi jalar, suhu ekstruder, dan kecepatan ulir ekstruder. Terdapat dua respon yang 
dianalisis pada penelitian ini yaitu kehilangan padatan akibat pemasakan (KPAP) dan elongasi, yang merupakan mutu utama produk mi (Tan et al., 2009). Angka yang diperoleh dari penentuan batas atas dan batas bawah pada penelitian pendahuluan dimasukkan ke dalam program DX7. Kombinasi yang dianalisis menggunakan RSM adalah 20 kombinasi.

\section{Pembuatan sohun ubi jalar}

Metode pembuatan sohun diadaptasi dari metode pembuatan mi jagung oleh Muhandri dan Subarna (2009). Proses pembuatan sohun diawali dengan melarutkan garam dalam air, lalu dicampur dengan pati ubi jalar menggunakan hand mixer (Philips, Indonesia) selama 3 menit. Setelah bahan tercampur menjadi adonan, adonan dimasukkan ke dalam ekstruder pemasak-pencetak ulir tunggal (Labtech Engineering Co. Ltd., Thailand) dengan ukuran diameter die 0,6 mm. Hasil ekstrusi berupa sohun ubi jalar basah yang kemudian dikeringkan menggunakan oven pengering (suhu $50^{\circ} \mathrm{C}$ selama 2 jam).

\section{Analisis kehilangan padatan akibat pemasakan (KPAP) (Smatanova dan Bartosova, 2014)}

Analisis KPAP pada penelitian ini ditentukan dengan cara merebus $5 \mathrm{~g}$ sohun di dalam $200 \mathrm{~mL}$ air selama 4 menit lalu ditiriskan. Sohun kemudian dikeringkan pada oven bersuhu $100^{\circ} \mathrm{C}$ sampai beratnya konstan. Analisis kadar air sohun metode oven (AOAC, 2005) dibutuhkan untuk mengetahui berat kering sohun. Perhitungan KPAP dilakukan dengan rumus berikut:

KPAP =

berat kering sampel sebelum direbus-berat kering sampel sesudah direbus $\times 100 \%$ berat kering sampel sebelum direbus

\section{Respon elongasi}

Analisis elongasi sohun menggunakan Texture Analyzer TA-XT2i (Stable Micro-System, England). Sohun direbus dalam air $200 \mathrm{~mL}$ bersuhu $92-100^{\circ} \mathrm{C}$ selama 4 menit lalu direndam dalam air bersuhu ruang $\left(28^{\circ} \mathrm{C}\right)$ selama 1 menit untuk kemudian dianalisis. Tujuan perendaman adalah memudahkan dalam pemisahan untaian sohun. Analisis dilakukan dengan melilitkan untaian sohun pada probe dengan jarak antar probe $2 \mathrm{~cm}$ dan kecepatan probe 0,3 $\mathrm{cm} / \mathrm{s}$. Pengukuran elongasi ini dilakukan sebanyak 3 kali. Elongasi dapat dihitung dengan cara berikut:

$$
\text { Elongasi }(\%)=\frac{\text { waktu putus sampel }(\mathrm{s}) \times 0,3 \mathrm{~cm} / \mathrm{s}}{2 \mathrm{~cm}} \times 100 \%
$$

\section{Optimasi formula dan proses}

Data hasil pengukuran kehilangan padatan akibat pemasakan (KPAP) dan elongasi sohun dimasukkan ke program DX7. Model yang memberikan signifikansi pada ANOVA dan nonsignifikan- si pada lack of fit dipilih untuk menganalisis variabel. Kombinasi optimum merupakan kombinasi yang menghasilkan sohun dengan KPAP minimum dan elongasi maksimum. Keluaran dari tahap optimasi adalah rekomendasi dari DX7 berupa beberapa formula dan kondisi proses yang optimum dengan nilai desirability masing-masing kombinasi formula dan proses. Kombinasi yang paling optimum adalah kombinasi dengan nilai desirability maksimum.

\section{Verifikasi hasil}

Kondisi optimum dari program DX7 diuji coba. Hasil analisis respon kemudian dibandingkan dengan respon prediksi. Verifikasi dinyatakan baik jika terdapat kesesuaian antara respon aktual dengan respon prediksi dan dapat diterima dalam interval tertentu yang ditetapkan program.

\section{Perbaikan mutu sohun ubi jalar}

Perbaikan mutu sohun dilakukan dengan menggunakan perlakuan pendinginan (pada suhu $4^{\circ} \mathrm{C}$ selama 6 jam) dan pembekuan $\left(-5^{\circ} \mathrm{C}\right.$ selama 8 jam) terhadap sohun yang keluar dari ekstruder, lalu sohun dikeringkan. Pengeringan dilakukan dengan dua cara yaitu pada oven pengering bersuhu $50^{\circ} \mathrm{C}$ selama 2 jam, dan dikeringanginkan pada suhu ruang selama 24 jam.

\section{HASIL DAN PEMBAHASAN}

\section{Karakteristik pati ubi jalar}

Secara visual, pati yang dihasilkan dari empat varietas memiliki warna putih, namun cenderung kusam jika dibandingkan dengan produk pati tapioka. Hal ini disebabkan oleh pigmen alami yang terdapat pada ubi jalar, seperti beta karoten. Penampakan pati ubi jalar dari keempat varietas disajikan pada Gambar 1.

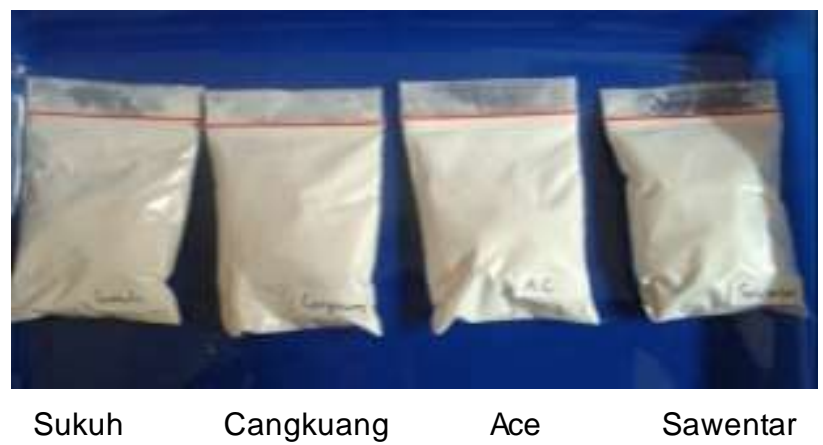

Gambar 1. Pati ubi jalar dari keempat varietas

Varietas berpengaruh secara signifikan $(P<$ $0,05)$ terhadap kadar abu, protein, lemak, karbohidrat, amilosa dan derajat putih (Tabel 2). Pati dari varietas Sukuh dan Ace memiliki kadar karbohidrat tertinggi. Pati ubi jalar varietas Ace memiliki kadar amilosa dan derajat putih yang tertinggi. 
Tabel 2. Karakteristik kimia dan fisik empat varietas pati ubi jalar

\begin{tabular}{|c|c|c|c|c|}
\hline \multirow{2}{*}{ Analisis } & \multicolumn{4}{|c|}{ Varietas } \\
\hline & Sukuh & Cangkuang & Ace & Sawentar \\
\hline Kadar air (\% bb) & $9,42 \pm 0,09^{a}$ & $11,67 \pm 0,25^{c}$ & $9,47 \pm 0,38^{\mathrm{a}}$ & $10,39 \pm 0,52^{0}$ \\
\hline Abu (\% bk) & $0,24 \pm 0,02^{\mathrm{a}}$ & $0,32 \pm 0,03^{\mathrm{D}}$ & $0,29 \pm 0,00^{\circ}$ & $0,29 \pm 0,02^{\mathrm{D}}$ \\
\hline Protein (\% bk) & $0,43 \pm 0,08^{\mathrm{a}}$ & $0,61 \pm 0,01^{\mathrm{D}}$ & $0,52 \pm 0,07^{\mathrm{a}}$ & $0,42 \pm 0,06^{\mathrm{a}}$ \\
\hline Lemak (\% bk) & $0,12 \pm 0,02^{\mathrm{a}}$ & $0,42 \pm 0,05^{\mathrm{D}}$ & $0,37 \pm 0,03^{\mathrm{D}}$ & $0,37 \pm 0,04^{\mathrm{D}}$ \\
\hline Karbohidrat (\% bk) & $99,16 \pm 0,09^{\mathrm{C}}$ & $96,12 \pm 0,32^{\mathrm{a}}$ & $98,71 \pm 0,41^{\mathrm{c}}$ & $97,81 \pm 0,49^{\circ}$ \\
\hline Amilosa (\% bk) & $8,36 \pm 0,82^{\mathrm{a}}$ & $8,26 \pm 0,47^{\mathrm{a}}$ & $8,77 \pm 0,33^{\circ}$ & $8,34 \pm 0,48^{\mathrm{a}}$ \\
\hline Derajatputih & $77,68 \pm 0,06^{c}$ & $73,86 \pm 0,29^{a}$ & $83,27 \pm 0,31^{a}$ & $76,29 \pm 0,42^{\mathrm{D}}$ \\
\hline
\end{tabular}

Keterangan: ${ }^{\text {aee }}$ Angka-angka pada baris yang sama yang diikuti oleh huruf yang sama tidak berbeda nyata pada taraf uji $5 \%$

Suhu gelatinisasi dari semua produk pati ubi jalar yang diuji berkisar antara 72,57 hingga $79,30^{\circ} \mathrm{C}$ (Tabel 3 dan Gambar 2). Kisaran suhu gelatinisasi tersebut sesuai dengan kisaran yang dikemukakan Tan et al. (2009), yaitu sekitar $67-88^{\circ} \mathrm{C}$. Suhu gelatinisasi memiliki hubungan dengan kadar amilosa pati, dimana semakin tinggi kadar amilosa pati, maka pada umumnya suhu gelatinisasi semakin tinggi. Pada produk pati ubi jalar yang diuji, kadar amilosa semua varietas tidak berbeda nyata, yaitu berada di sekitar $8 \%$, sehingga tidak dapat dilihat pengaruh kadar amilosa dengan suhu gelatinisasi. Viskositas puncak (maximum viscosity) produk pati dari keempat varietas ubi jalar berkisar antara 5183,33 hingga $6570,33 \mathrm{cP}$ (Tabel 3). Varietas Cangkuang dan Ace memiliki nilai viskositas puncak terendah, dan varietas Sukuh memiliki nilai viskositas puncak yang tertinggi.

Breakdown viscosity (BV) produk pati dari empat varietas ubi jalar memiliki nilai 5183,33 hingga $6570,33 \mathrm{cP}$. Varietas Sukuh memiliki nilai BV paling tinggi, sedangkan Ace memiliki nilai BV paling rendah. Nilai BV menunjukkan kestabilan pati selama pemanasan. Semakin tinggi BV, semakin rendah kestabilan pati terhadap pemanasan, karena itu berarti pasta pati semakin kehilangan sifat kekentalannya. Hilangnya kekentalan pasta pati disebabkan oleh pecahnya granula pati setelah melewati ukuran maksimum granula pati karena pemanasan yang kontinyu. Hal ini menyebabkan granula pati melepas amilosa dan amilopektin dari granula, dan kerusakan ini bersifat irreversible. Salah satu keistimewaan pati ubi jalar adalah pati ubi jalar memiliki nilai BV yang sangat rendah dibanding pati alami lain (Zaidul et al., 2007). Setback viscosity (SV) pati dari empat varietas ubi jalar memiliki nilai 1090,33 hingga 1328,00 cP. Varietas Sukuh memiliki nilai SV paling rendah, sedangkan Ace dan Sawentar memiliki nilai SV paling tinggi. Nilai SV menunjukkan kemampuan pasta pati untuk mengalami proses retrogradasi. Setback viscosity juga memiliki hubungan dengan kadar amilosa, dimana semakin tinggi kadar amilosa, maka semakin tinggi nilai setback viscosity, karena setback viscosity adalah indikasi kecenderungan retrogradasi. Parameter SV menjadi penting, karena pati yang memiliki nilai SV yang tinggi baik untuk pembuatan produk pasta dari ubi jalar (Zaidul et al., 2007).

Varietas Ace memiliki karakteristik kimia dan fisik yang lebih unggul dibandingkan dengan ketiga varietas yang lain untuk pembuatan sohun. Pati varietas Ace memiliki kadar karbohidrat dan total pati paling tinggi, memiliki swelling power dan gel strength lebih rendah serta Setback Viscosity yang lebih tinggi. Pati ubi jalar varietas Ace digunakan untuk penelitian optimasi pembuatan sohun pati ubi jalar.

\section{Respon sohun ubi jalar}

Respon yang dianalisis untuk menentukan optimasi sohun ubi jalar adalah kehilangan padatan akibat pemasakan (KPAP) dan elongasi. Semakin rendah nilai KPAP sohun menunjukkan bahwa sohun memiliki tekstur yang baik dan homogen (Tan et al., 2009). Elongasi tinggi menunjukkan karakteristik sohun yang tidak mudah putus. Sifat ini penting karena konsumen tidak menginginkan sohun yang hancur saat dimasak. Hasil analisis respon sohun ubi jalar berdasarkan empat faktor yang dipelajari yaitu jumlah air, jumlah pati ubi jalar, suhu ekstruder, dan kecepatan ulir ekstruder dapat dilihat pada Tabel 4.

\section{Respon kehilangan padatan akibat pemasakan (KPAP) sohun ubi jalar}

Kehilangan padatan akibat pemasakan atau cooking loss merupakan banyaknya padatan mi basah yang keluar atau terlarut ke dalam air selama proses pemasakan. Nilai KPAP dinyatakan sebagai perbandingan berat padatan yang terlepas per berat kering sampel dan dinyatakan dalam satuan persen (\%). Semakin rendah nilai KPAP menunjukkan bahwa mi tersebut memiliki tekstur yang baik dan homogen (Wang et al., 2012). Model prediktor untuk respon KPAP sohun ubi jalar adalah model quadratic dan mean. Model ini memiliki nilai $R$ squared 0.4828. Model matematik untuk respon KPAP sohun ubi jalar adalah sebagai berikut:

$$
\mathrm{KPAP}=11,0026 \mathrm{~A}+38,3120 \mathrm{~B}-0,8951 \mathrm{AB}
$$

Keterangan: $\mathrm{A}=$ Pati ubi jalar (g); $\mathrm{B}=$ Air (g) 


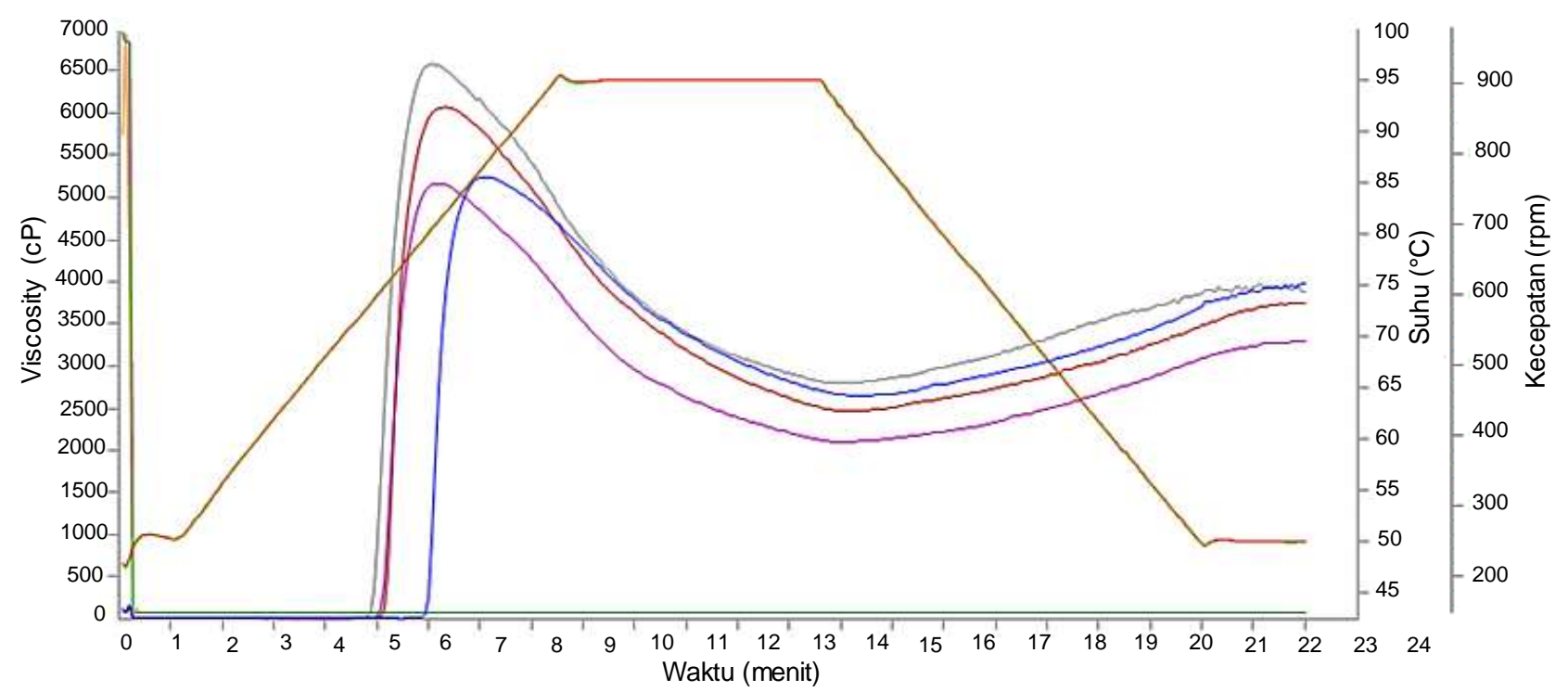

Keterangan:

: Sukuh

: Ace : Cangkuang

: Saw entar

Gambar 2. Grafik perbandingan antar profil gelatinisasi pati ubi jalar dari varietas yang berbeda

Tabel 3. Data profil gelatinisasi pada empat varietas pati ubi jalar

\begin{tabular}{lcccc}
\hline \multicolumn{1}{c}{ Varietas } & $\begin{array}{c}\text { Suhu Gelatinisasi } \\
\left({ }^{\circ} \mathrm{C}\right)\end{array}$ & $\begin{array}{c}\text { Peak Viscosity } \\
(\mathrm{cP})\end{array}$ & $\begin{array}{c}\text { Breakdown Viscosity } \\
(\mathrm{cP})\end{array}$ & $\begin{array}{c}\text { Setback Viscosity } \\
(\mathrm{cP})\end{array}$ \\
\hline Sukuh & $72,57 \pm 0,25^{\mathrm{a}}$ & $6570,33 \pm 37,58^{\mathrm{c}}$ & $3774,00 \pm 33,96^{\mathrm{a}}$ & $1090,33 \pm 52,99^{\mathrm{a}}$ \\
Cangkuang & $73,73 \pm 0,03^{\mathrm{D}}$ & $5183,33 \pm 24,38^{\mathrm{a}}$ & $3081,33 \pm 19,55^{\mathrm{D}}$ & $1205,33 \pm 10,21^{\mathrm{D}}$ \\
Ace & $79,30 \pm 0,00^{\mathrm{a}}$ & $5234,67 \pm 23,16^{\mathrm{a}}$ & $2605,67 \pm 15,04^{\mathrm{a}}$ & $1328,00 \pm 14,73^{\mathrm{c}}$ \\
Sawentar & $74,12 \pm 0,03^{\mathrm{c}}$ & $6077,33 \pm 48,64^{\mathrm{D}}$ & $3609,33 \pm 36,56^{\mathrm{C}}$ & $1291,00 \pm 10,15^{\mathrm{c}}$ \\
\hline
\end{tabular}

Keterangan: ${ }^{\mathrm{a}-\mathrm{d}}$ Angka-angka pada kolom yang sama yang diikuti oleh huruf yang sama tidak berbeda nyata pada taraf uji $5 \%$ (uji Duncan)

Tabel 4. Data hasil analisis kombinasi sohun ubi jalar

\begin{tabular}{|c|c|c|c|c|c|c|c|c|}
\hline \multirow{2}{*}{ Std } & \multirow{2}{*}{ Pati (g) } & \multirow{2}{*}{ Air (g) } & \multirow{2}{*}{$\begin{array}{l}\text { Suhu } \\
\left({ }^{\circ} \mathrm{C}\right)\end{array}$} & \multirow{2}{*}{$\begin{array}{l}\text { Kecepatan } \\
\text { Ulir (rpm) }\end{array}$} & \multicolumn{2}{|c|}{ Kadar Air } & \multirow{2}{*}{$\begin{array}{c}\text { KPAP } \\
(\%)\end{array}$} & \multirow{2}{*}{$\begin{array}{c}\text { Elongasi } \\
(\%)\end{array}$} \\
\hline & & & & & $\%$ bb & \%bk & & \\
\hline 1 & 62,5 & 37,5 & 80 & 80 & $8,65 \pm 0,05$ & $9,46 \pm 0,06$ & 23,01 & 107,08 \\
\hline 2 & 69,0 & 31,0 & 80 & 80 & $8,42 \pm 0,05$ & $9,19 \pm 0,06$ & 26,33 & 76,88 \\
\hline 3 & 69,0 & 31,0 & 80 & 120 & $11,90 \pm 0,12$ & $13,50 \pm 0,15$ & 31,55 & 81,34 \\
\hline 4 & 62,5 & 37,5 & 90 & 120 & $12,23 \pm 0,17$ & $13,93 \pm 0,22$ & 20,97 & 189,73 \\
\hline 5 & 62,5 & 37,5 & 90 & 80 & $12,34 \pm 0,04$ & $14,08 \pm 0,05$ & 25,41 & 162,32 \\
\hline 6 & 65,8 & 34,2 & 90 & 80 & $12,03 \pm 0,21$ & $13,67 \pm 0,27$ & 15,07 & 153,08 \\
\hline 7 & 65,8 & 34,2 & 90 & 120 & $10,31 \pm 0,17$ & $11,49 \pm 0,21$ & 24,50 & 117,80 \\
\hline 8 & 65,8 & 34,2 & 85 & 100 & $11,56 \pm 0,14$ & $13,07 \pm 0,18$ & 13,06 & 115,33 \\
\hline 9 & 69,0 & 31,0 & 85 & 100 & $11,44 \pm 0,04$ & $12,92 \pm 0,05$ & 36,45 & 87,64 \\
\hline $\begin{array}{l}10 \\
11\end{array}$ & $\begin{array}{l}62,5 \\
69,0\end{array}$ & $\begin{array}{l}37,5 \\
31,0\end{array}$ & $\begin{array}{l}80 \\
90\end{array}$ & $\begin{array}{l}100 \\
100\end{array}$ & $\begin{array}{c}11,34 \pm 0,03 \\
9,25 \pm 0,15\end{array}$ & $\begin{array}{l}12,78 \pm 0,03 \\
10,19 \pm 0,18\end{array}$ & $\begin{array}{l}32,71 \\
33,99\end{array}$ & $\begin{array}{c}33,53 \\
108,36\end{array}$ \\
\hline 12 & 64,1 & 35,9 & 90 & 100 & $10,01 \pm 0,09$ & $11,12 \pm 0,11$ & 19,72 & 163,88 \\
\hline 13 & 64,1 & 35,9 & 85 & 120 & $10,56 \pm 0,05$ & $11,81 \pm 0,06$ & 14,76 & 193,37 \\
\hline 14 & 67,4 & 32,6 & 85 & 80 & $11,95 \pm 0,11$ & $13,57 \pm 0,11$ & 32,74 & 114,77 \\
\hline 15 & 69,0 & 31,0 & 85 & 120 & $10,98 \pm 0,16$ & $12,33 \pm 0,20$ & 29,51 & 103,78 \\
\hline 16 & 64,1 & 35,9 & 83 & 90 & $12,52 \pm 0,07$ & $14,31 \pm 0,09$ & 29,72 & 163,37 \\
\hline 17 & 69,0 & 31,0 & 80 & 120 & $8,25 \pm 0,13$ & $8,99 \pm 0,15$ & 32,01 & 38,81 \\
\hline 18 & 62,5 & 37,5 & 90 & 80 & $8,23 \pm 0,12$ & $8,97 \pm 0,15$ & 24,20 & 89,60 \\
\hline 19 & 62,5 & 37,5 & 83 & 90 & $7,63 \pm 0,26$ & $8,26 \pm 0,30$ & 33,30 & 137,89 \\
\hline 20 & 69,0 & 31,0 & 80 & 120 & $7,75 \pm 0,21$ & $8,40 \pm 0,25$ & 28,25 & 67,43 \\
\hline
\end{tabular}

Jumlah pati, jumlah air, serta interaksi antara pati dan air dinyatakan berpengaruh secara signifikan terhadap nilai KPAP sohun ubi jalar $(\alpha=0,05)$. Suhu dan kecepatan ulir ekstruder tidak berpe- ngaruh secara signifikan terhadap nilai KPAP sohun ubi jalar $(\alpha=0,05)$. Grafik RSM untuk respon KPAP (Gambar 3) menunjukkan bahwa nilai KPAP terendah terdapat pada jumlah pati $65,8 \mathrm{~g}$ dan jumlah 
air 34,2 g. Interaksi antara pati dan air harus diperhatikan untuk menghasilkan sohun dengan KPAP yang rendah. Penggunaan air yang terlalu sedikit atau terlalu banyak dapat menyebabkan nilai KPAP menjadi tinggi. Peningkatan kadar air dapat menyebabkan peningkatan derajat gelatinisasi pati. Peningkatan derajat gelatinisasi berarti bahwa semakin banyak amilosa yang lepas dari granula pati, semakin banyak amilosa yang dapat berfungsi sebagai pengikat dan mencegah komponen-komponen mi terlepas saat dimasak (Tan et al., 2009). Gelatinisasi pati tidak akan terjadi jika air yang tersedia sangat sedikit. Terlalu banyak air juga tidak baik karena dapat mengakibatkan adonan yang terbentuk lengket sehingga adonan sulit ditangani dan dicetak (Fu, 2007). KPAP untuk semua jenis mi yang dapat diterima oleh Chinese Agricultural Standards dan Thai Standards adalah kurang dari 10\% (Tan et al., 2009). Sohun ubi jalar pada penelitian ini masih memiliki KPAP yang tinggi yaitu $13,06-36,45 \%$. Hal tersebut disebabkan oleh rendahnya amilosa pada ubi jalar varietas Ace yaitu $8,77 \pm 0,33 \%$ bk. KPAP dipengaruhi oleh rasio amilosa dan amilopektin. Amilosa mudah membentuk gel karena strukturnya yang linier sehingga memudahkan pembentukan jaringan tiga dimensi.

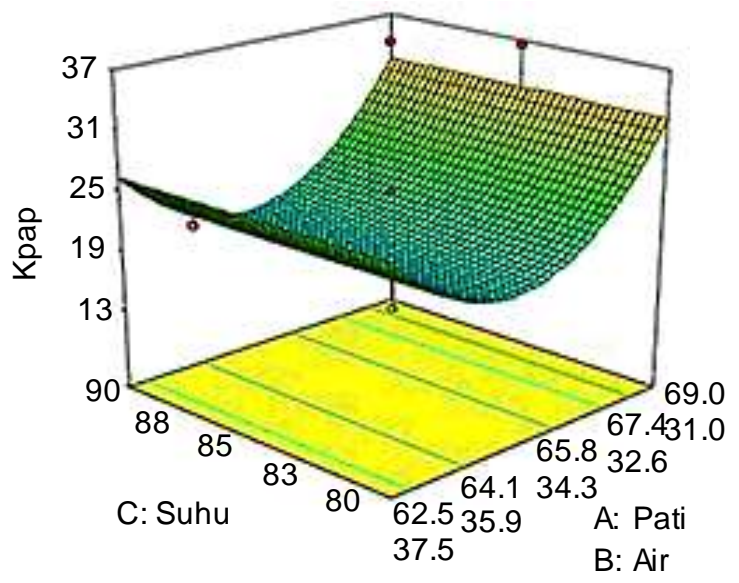

Gambar 3. Respon surface untuk kehilangan padatan akibat pemasakan dari sohun ubi jalar sebagai pengaruh dari pati ubi jalar, air dan suhu ekstruder

Semakin rendah kandungan amilosa, menyebabkan struktur gel yang terbentuk lemah. Lemahnya struktur gel pati menyebabkan padatan terlarut lebih besar sehingga susut masaknya semakin besar (Rahim et al., 2009). Selain itu, tingkat KPAP tergantung pada derajat gelatinisasi. Semakin tinggi derajat gelatinisasi, maka KPAP-nya akan semakin rendah. Pada mi berbasis pati, KPAP disebabkan oleh kelarutan pati tergelatinisasi yang ikatannya lemah di permukaan mi (Charutigon et al., 2008). KPAP yang tinggi tidak diinginkan karena menghasilkan air rebusan yang keruh.

\section{Respon elongasi sohun ubi jalar}

Elongasi adalah pertambahan panjang mi akibat gaya tarikan (Muhandri dan Subarna, 2009). Model prediktor untuk respon elongasi sohun ubi jalar adalah model quadratic dan mean. Model ini memiliki nilai $R$ squared 0,4545 . Persamaan RSM menunjukkan bahwa variabel bebas jumlah pati ubi jalar, jumlah air, dan interaksi keduanya berpengaruh secara signifikan terhadap elongasi sohun ubi jalar $(\alpha=0,05)$. Model matematik untuk respon elongasi sohun ubi jalar adalah sebagai berikut:

$$
\text { Elongasi }=-59,7026 \mathrm{~A}-210,6550 \mathrm{~B}+5,0156 \mathrm{AB}
$$

Keterangan: $A=$ Pati ubi jalar $(\mathrm{g}) ; \mathrm{B}=\mathrm{Air}(\mathrm{g})$

Grafik RSM untuk respon elongasi yang disajikan pada Gambar 4 menunjukkan bahwa jumlah pati dan jumlah air harus berada dalam kombinasi yang tepat. Jumlah air yang semakin meningkat pada kombinasi dapat meningkatkan nilai elongasi. Hal tersebut sesuai dengan Wang et al. (2012) yang menyatakan bahwa kenaikan kadar air meningkatkan derajat gelatinisasi. Tingginya amilosa terlarut dan tingginya kemampuan pengembangan granula mampu meningkatkan elastisitas mi. Sebaliknya, tingginya amilopektin terlarut dapat mengganggu pembentukan gel dan menurunkan elastisitas. Hal ini menunjukkan kecukupan gelatinisasi sangat menentukan sifat elongasi mi. Kecukupan gelatinisasi pati sangat dipengaruhi oleh jumlah air yang digunakan. Suhu ekstruder dan kecepatan ulir ekstruder yang digunakan tidak berpengaruh secara signifikan $(\alpha=0,05)$ terhadap elongasi sohun.

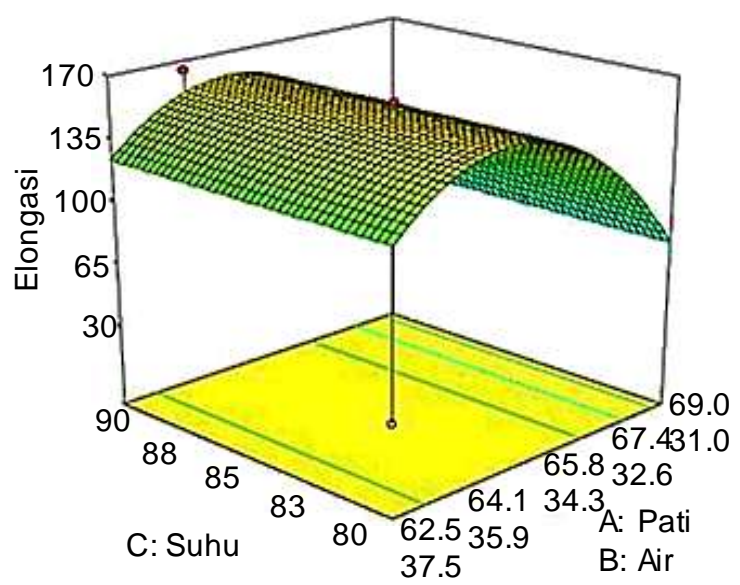

Gambar 4. Respon elongasi sohun ubi jalar sebagai pengaruh dari pati ubi jalar, air dan suhu ekstruder

Hal tersebut tidak sesuai dengan penelitian yang telah dilakukan Muhandri et al. (2011) bahwa peningkatan suhu ekstruder dan kecepatan ulir ekstruder dapat meningkatkan elongasi mi. Menurut Marti et al. (2011) kekokohan struktur pada mi dari 
tepung beras dipengaruhi tingkat gelatinisasi granula pati, dimana semakin tinggi suhu ekstruder, semakin tinggi pula tingkat gelatinisasi dan mi semakin kokoh strukturnya. Gelatinisasi yang tinggi pada adonan selama proses ekstrusi menyebabkan kekuatan struktur gel semakin tinggi sehingga mi semakin tinggi elongasinya. Suhu ekstruder yang digunakan pada penelitian dianggap sudah menyentuh derajat gelatinisasi optimal sehingga tidak berpengaruh secara signifikan terhadap elongasi sohun. Kecepatan ulir ekstruder pada penelitian ini tidak berpengaruh secara signifikan terhadap elongasi sohun. Amilosa telah tersebar secara merata pada adonan sohun selama berada di dalam eks truder pada kisaran kecepatan ulir yang digunakan pada penelitian ini. Kondisi ini berbeda dengan Muhandri (2012), yang menyatakan bahwa elongasi mi berbahan baku tepung jagung meningkat dengan meningkatnya kecepatan ulir ekstruder. Hal ini disebabkan oleh perbedaan bahan baku yang digunakan.

\section{Kombinasi optimum dan verifikasi}

Kombinasi optimum untuk membuat sohun ubi jalar yang dihasilkan program adalah jumlah pati $65,2 \%$, jumlah air $34,8 \%$, suhu ekstruder $89^{\circ} \mathrm{C}$, dan kecepatan ulir ekstruder $107 \mathrm{rpm}$ (Tabel 5). Nilai desirability untuk kombinasi tersebut adalah 0,749. Kisaran nilainya dari 0 sampai 1,0 . Nilai desirability yang semakin mendekati nilai 1,0 menunjukkan kemampuan program untuk menghasilkan produk yang dikehendaki semakin sempurna. Tujuan opti- masi bukan untuk memperoleh nilai desirability 1,0 namun untuk mencari kondisi terbaik yang mempertemukan semua fungsi tujuan (Raissi dan Farzani, 2009). Verifikasi hasil dilakukan terhadap hasil prediksi optimasi untuk menyesuaikan hasil prediksi yang diberikan oleh perangkat lunak DX-7 dengan hasil aktual yang dilakukan. Nilai aktual KPAP dan elongasi masih sesuai dengan prediksi yang dibuat oleh program DX7 (Tabel 6). Hal tersebut ditunjukkan dengan nilai kedua respon memenuhi 95\% confident interval yang disajikan program.

\section{Mutu sohun setelah perbaikan teknik penge- ringan}

Perlakuan tambahan dilakukan dengan cara pendinginan refrigerator dan pembekuan freezer sohun setelah keluar dari ekstruder, sedangkan perbedaan perlakuan terdapat pada metode pengeringan sohun. Data pada Tabel 7 menunjukkan hasil analisis respon dengan berbagai perlakuan. Sohun komersial berbahan dasar pati kacang hijau dianalisis hanya sebagai pembanding. Secara visual terdapat perbaikan mutu sohun kering maupun sohun setelah rehidrasi (Gambar 5 dan Gambar 6). Perlakuan pendinginan dan pembekuan pada sohun setelah keluar dari ekstruder mampu menurunkan nilai KPAP dan meningkatkan elongasi sohun ubi jalar secara signifikan $(\alpha=0,05)$. Nilai KPAP sohun tanpa pendinginan dan pembekuan adalah 22,09\% untuk pengeringan oven dan $19,31 \%$ untuk pengeringan angin.

Tabel 5. Hasil optimasi sohun ubi jalar dengan menggunakan DX7

\begin{tabular}{lccccccc}
\hline & Pati $(\mathrm{g})$ & Air $(\mathrm{g})$ & Suhu $\left({ }^{\circ} \mathrm{C}\right)$ & Kec, Ulir $(\mathrm{rpm})$ & KPAP $(\%)$ & Elongasi $(\%)$ \\
\hline Target & In range & In range & In range & In Range & Minimize & Target \\
Lower & 62,5 & 31,0 & 80 & 80 & 13,06 & 190 \\
Upper & 69,0 & 37,5 & 90 & 120 & 36,45 & 200 & \\
Importance & +++ & +++ & +++ & +++ & +++ & +++ & desirability \\
Solution & & & & & & & \\
1 (selected) & 65,2 & 34,8 & 89 & 107 & 19,79 & 156,96 & 0,749 \\
\hline
\end{tabular}

Tabel 6. Hasil verifikasi optimasi sohun ubi jalar antara prediksi dan aktual

\begin{tabular}{lccccccc}
\hline \multirow{2}{*}{ Respon } & \multirow{2}{*}{ Prediksi } & \multirow{2}{*}{ SE Mean } & \multirow{2}{*}{ 95\% CI Low } & \multirow{2}{*}{$95 \%$ CI High } & \multicolumn{3}{c}{ Aktual } \\
\cline { 5 - 8 } & & & & U1 & U2 & Rata-rata \\
\hline KPAP $(\%)$ & 19,79 & 2,29 & 14,95 & 24,63 & 19,93 & 21,77 & 20,85 \\
Elongasi $(\%)$ & 156,96 & 15,46 & 124,28 & 189,52 & 162,75 & 167,21 & 164,98 \\
\hline
\end{tabular}

Tabel 7. Kehilangan padatan akibat pemasakan dan elongasi sohun ubi jalar setelah perbaikan teknik pengeringan

\begin{tabular}{|c|c|c|}
\hline \multirow{2}{*}{ Perlakuan } & \multicolumn{2}{|c|}{ Respon } \\
\hline & KPAP (\%) & Elongasi (\%) \\
\hline Sohun komersial** & $3,20 \pm 1,62$ & $210,42 \pm 6,75$ \\
\hline Pengeringan oven & $22,09 \pm 0,86^{\mathrm{C}}$ & $152,89 \pm 0,64^{a}$ \\
\hline Pengeringan angin & $19,31 \pm 0,11^{\mathrm{D}}$ & $176,72 \pm 1,26^{\mathrm{D}}$ \\
\hline Pendinginan + pembekuan + pengeringan oven & $13,08 \pm 0,41^{\mathrm{a}}$ & $187,17 \pm 2,56^{\mathrm{c}}$ \\
\hline Pendinginan + pembekuan + pengeringan angin & $12,90 \pm 0,10^{\mathrm{a}}$ & $196,42 \pm 2,22^{a}$ \\
\hline
\end{tabular}




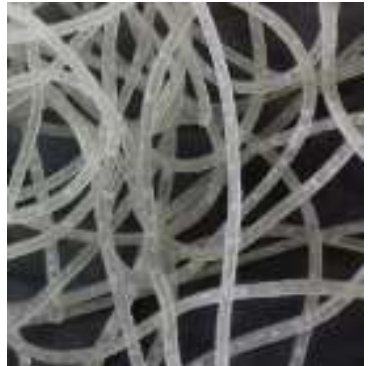

A

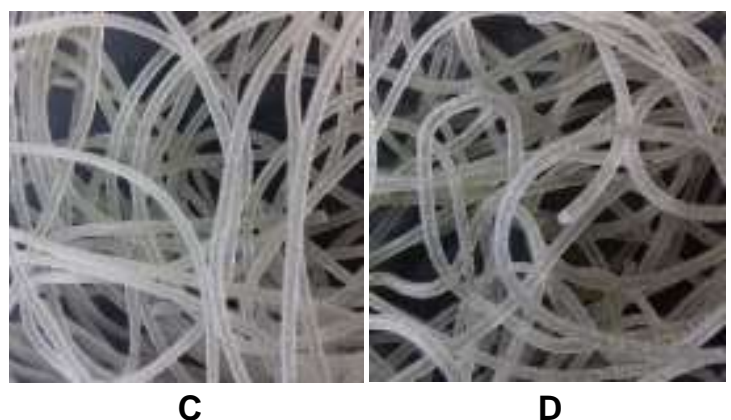

Keterangan: $\mathrm{PO}=$ Pengeringan oven $; \mathrm{PA}=$ Pengeringan angin; $\mathrm{DBPO}=$ Pendinginan + pembekuan + pengeringan oven; $\mathrm{DBPA}=$ Pendinginan + pembekuan + pengeringan angin

Gambar 5. Sohun ubi jalar kering (A) PO; (B) PA; (C) DBPO; (D) DBPA

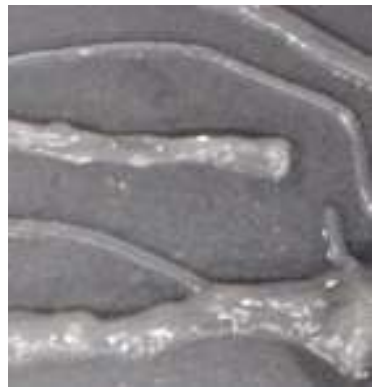

A

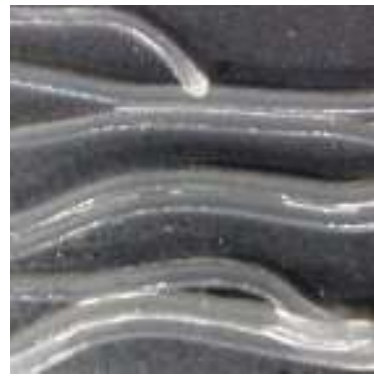

$C$

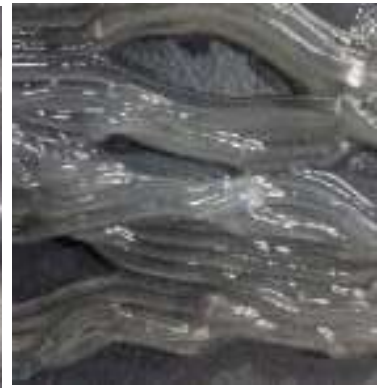

B

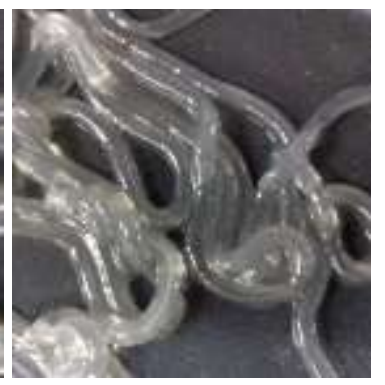

D
Keterangan: $\mathrm{PO}=$ Pengeringan oven $; \mathrm{PA}=$ Pengeringan angin; $\mathrm{DBPO}=$ Pendinginan + pembekuan + pengeringan oven; $\mathrm{DBPA}=$ Pendinginan + pembekuan + pengeringan angin

Gambar 6. Sohun ubi jalar setelah rehidrasi PO; (B) PA; (C) DBPO; (D) DBPA
Nilai KPAP berkurang secara signifikan $(\alpha=0,05)$ pada sohun dengan perlakuan pendinginan dan pembekuan yaitu $13,08 \%$ untuk pengeringan oven dan $12,90 \%$ untuk pengeringan angin. Nilai KPAP sohun ubi jalar masih lebih tinggi jika dibandingkan dengan sohun komersial dari pati kacang hijau (Tabel 7). Proses pendinginan dan pembekuan dapat menurunkan nilai KPAP karena ikatan hidrogen antara molekul amilosa dan amilopektin akan semakin kuat apabila dilakukan proses pendinginan atau pembekuan. Ikatan hidrogen yang kuat ini menyebabkan molekul-molekul amilosa dan amilopektin cenderung membentuk ikatan hidrogen sesama sendiri sehingga gel pati semakin kompak.

Pendinginan dan pembekuan merupakan proses yang penting pada industri pembuatan sohun. Selama proses pendinginan, pati yang telah tergelatinisasi akan mengalami rekristalisasi. Tahap ini dapat disebut sebagai retrogradasi jangka pendek dengan amilosa yang memiliki peranan penting. Pada tahap pembekuan, amilopektin juga berkontribusi terhadap proses retrogradasi (Chen et al., 2002). Selain itu, Chen et al. (2002) juga telah meneliti bahwa proses pendinginan dan pembekuan dapat meningkatkan transparansi sohun kering, menurunkan kelengketan, dan memudahkan dalam pemisahan untaian sohun. Metode pengeringan berpengaruh nyata $(\alpha=0,05)$ terhadap nilai KPAP pada sohun tanpa pendinginan dan pembekuan. Sohun dengan pengeringan oven memiliki KPAP $22,09 \%$, sedangkan sohun dengan pengeringan angin memiliki KPAP yang lebih rendah yaitu $19,31 \%$. Pengeringan angin dapat meningkatkan nilai elongasi secara nyata baik pada sohun tanpa perlakuan tambahan, maupun pada sohun dengan pendinginan dan pembekuan. Metode pengeringan dengan oven tidak disarankan karena pengeringan yang terlalu cepat dapat mengakibatkan perbedaan kelembaban yang cukup besar antara permukaan luar sohun dengan bagian dalam sohun. Penerapan metode pengeringan yang tidak tepat dapat merusak struktur sohun, menyebabkan elongasi yang rendah, serta retak pada sohun (Fu, 2008).

Metode pengeringan sangat berpengaruh terhadap karakteristik dan tekstur sohun setelah pemasakan. Penggunaan suhu yang lebih rendah selama pengeringan dapat mencegah perubahan struktur sohun yang tidak diinginkan. Hal tersebut karena proses retrogradasi sohun terjadi secara perlahan serta daya tarikan dan tekanan yang terjadi di dalam sohun akibat berkurangnya air secara mendadak dapat dihindari (Fu, 2008). Berdasarkan analisis peningkatan mutu respon, maka sohun dengan mutu terbaik yaitu nilai KPAP terendah dan elongasi tertinggi terdapat pada sohun dengan perlakuan pendinginan, pembekuan, dan pengeringan angin. 


\section{KESIMPULAN}

Pati ubi jalar varietas Ace memiliki kadar karbohidrat, total pati dan amilosa paling tinggi, memiliki ketahanan dalam pemasakan paling baik, serta memiliki kecenderungan retrogradasi paling tinggi. Karakteristik yang dimiliki oleh pati ubi jalar varietas Ace lebih bagus dibandingkan dengan ketiga varietas lain untuk pembuatan sohun. Jumlah pati, jumlah air, serta interaksi antara pati dan air berpengaruh nyata terhadap KPAP sohun ubi jalar. Suhu ekstruder dan kecepatan ulir ekstruder berpengaruh nyata terhadap respon elongasi sohun ubi jalar. Nilai elongasi meningkat jika suhu ekstruder dan kecepatan ulir ekstruder ditingkatkan. Perlakuan optimum untuk membuat sohun ubi jalar menggunakan ekstruder ulir tunggal adalah jumlah pati $65,2 \mathrm{~g}$, jumlah air $34,8 \mathrm{~g}$, suhu ekstruder $89^{\circ} \mathrm{C}$ dan kecepatan ulir ekstruder 107 rpm. Kombinasi optimum tersebut memiliki nilai desirability sebesar 0,749 . Sohun ubi jalar yang dihasilkan dari kombinasi optimum memiliki KPAP 20,85\% dan elongasi $164,98 \%$. Proses pendinginan dan pembekuan yang diberikan terhadap sohun dan dilanjutkan dengan metode pengeringan kipas angin dapat memperbaiki mutu sohun dengan penurunan KPAP dan peningkatan elongasi.

\section{DAFTAR PUSTAKA}

[AOAC] Association of Official Analitycal Chemistry. 2005. Official Methods of Analysis of The Association Analytical Chemist. Inc. Virginia (US): AOAC.

Adedotun $\mathrm{H}$, Adebowale AA, Olayiwola 10 , Shittu TA, Sanni LO. 2015. Production and quality evaluation of noodles from sweet potato starch. J Culinary Sci Technol 13: 79-93. DOI: 10.10 80/15428052.2014.952479.

Astawan M, Widowati S. 2011. Evaluation of nutrition and glycemic index of sweet potatoes and its appropriate processing to hypoglycemic foods. Indonesian J Agr Sci 12: 40-46. DOI: 10.21082/ijas.v12n1.2011.p40-46.

Charutigon C, Jintana J, Pimjai N, Vilai R. 2008. Effects of processing conditions and the use of modified starch and monoglyseride on some properties of extruded rice vermicelli. LWTFood Sci Technol 41: 642-651. DOI: 10.1016/ j.Iwt.2007.04.009.
Chen Z, Sagis L, Legger JPH, Linssen, Schols HA, Voragen AGJ. 2002. Evaluation of starch noodles made from three typical chinese sweet potato starches. J Food Sci 67: 3342-3347. DOI: 10.1111/j.1365-2621.2002.tb09589.x.

Fu BX. 2008. Asian noodles: history, classification, raw materials, and processing. Food Res Int 41: 888-902. DOI: 10.1016/j.foodres.2007.11.007.

Juliano BO. 1971. A simplified assay for milled rice amylose. Cereal Sci Today 16: 334-360.

Marti A, Pagani MA, Seetharaman K. 2011. Understanding starch organization in glutenfree pasta from rice flour. Carbohyd Polym 84: 1069-1074. DOI: 10.1016/j.carbpol.2010.12. 070.

Muhandri T, Subarna. 2009. Pengaruh kadar air, $\mathrm{NaCl}$, dan jumlah passing terhadap karakterisrik reologi mie jagung. $\mathrm{J}$ Teknol Industri Pangan 22: 71-77.

Muhandri T, Ahza AB, Syarief R, Sutrisno. 2011. Optimasi proses ekstrusi mi jagung dengan metode permukaan respon. J Teknol Industri Pangan 22: 97-104.

Muhandri T. 2012. Mekanisme proses pembuatan mi berbahan baku jagung. Bul Teknol Pascapanen Pertanian 8: 71-79.

Noda T, Tsuda S, Mori M, Takigawa S, MatsuuraEndo C, Kim, SJ, Hashimoto N, Yamauchi H. 2006. Effect of potato starch properties on instant noodle quality in wheat flour and potato starch blends. Starch/Stärke 58: 18-24. DOI: 10.1002/star.200500439.

Noda T, Takigawa S, Endo CM, Ishiguro $\mathrm{K}$, Nagasawa K, Jinno. 2015. Properties of calcium-fortified potato starch prepared by immersion in natural mineral water and its food application. J Appl Glycosci 62: 159-164. DOI: 10.5458/jag.jag.JAG-2015_018.

Rahim A, Mappiratu, Noviyanty A. 2009. Sifat fisikokimia dan sensoris sohun instan dari pati sagu. J Agroland 16: 124-129.

Raissi S, Farzani RE. 2009. Statistical process optimization through multi-response surface methodology. Int $J$ Math Comp Phy Elect Comp Eng 3: 197-201.

Smatanova N, Bartosova M. 2014. Noodle quality of winter wheat cultivated in sustainable farming systems. J Central European Agric 15: 84-94. DOI: 10.5513/JCEA01/15.2.1457. 
Tan HZ, Li ZG, Tan B. 2009. Starch noodles: history, classification, materials, processing, structure, nutrition, quality evaluating and improving. Food Res 42: 551-556. DOI: 10.1016/j.foodres. 2009.02.015.

Thao HM, Noomhorm A. 2011. Physiochemical properties of sweet potato and mungbean starch and their blends for noodle production. $J$ Food Process Technol 2: 1-9. DOI: 10.4172/ 2157-7110.1000105.

Wang N, Maximiuk L, Toews R. 2012. Pea starch noodles: Effect of processing variables on characteristics and optimisation of twin-screw extrusion process. Food Chem 133: 742-753. DOI: 10.1016/j.foodchem.2012.01.087.
Widowati S, Herawati H, Mulyani ES, Yuliwardi F, Muhandri T. 2014. Pengaruh perlakuan heat moisture treatment (HMT) terhadap sifat fisikokimia dan fungsional tepung beras dan aplikasinya dalam pembuatan bihun berindeks glikemik rendah. J Penelitian Pascapanen Pertanian 11: 59-66. DOI: 10.21082/jpasca.v11 n2.2014.59-66.

Zaidul ISM, Yamauchi H, Takigawa S, MatsuuraEndo C, Suzuki T, Noda T. 2007. Correlation between the compositional and pasting properties of various potato starches. Food Chem 105: 164-172. DOI: 10.1016/j.foodchem.2007. 03.061. 